\title{
Perceived Impact of Effective Educational Planning and Implementation on Educational System for National Cohesion and Global Competitiveness
}

\author{
Osegbue Gloria Chineze \\ Department of Education Foundation, Chukwuemeka Odumegwu Ojukwu University Igbarian Campus, Nigeria
}

\begin{abstract}
The paper investigated impact of effective educational planning and implementation on education system in Anambra State, Nigeria. Three research questions and a null hypothesis guided the study. The population of the study was all the principals in the six education zones in the state numbering 257. A self-developed structured questionnaire was used for data collection. Data were analysed with mean, standard deviation and t-test was used to test the null hypothesis. Findings of this study revealed among others that the budgetary allocation on education is grossly insufficient and most educational policies in the area of science and technology are not being properly implemented. It was recommended among others that schools should be equipped with functional libraries, laboratories, workshops and that government should review the budgetary allocation on education to at least the 26 per cent recommended minimum by UNESCO.
\end{abstract}

Keywords: Education, Planning, Implementation, National Cohesion, Global Competitiveness.

DOI: $10.7176 / \mathrm{JEP} / 10-11-06$

Publication date: April $30^{\text {th }} 2019$

\section{Introduction}

Education over the years has witnessed series of definitions however, it still maintained its position as the pivot on which the wheel of progress of any nation rotates. Ifeanacho (2016) defined education as the fulcrum of the development and growth of any nation. Aluwong (2013) opined that education is the key to national development which unlocks the economic potentials of the nation; empowers and equip individuals; facilitates economic development and provides basis for transformation. This definition goes to support Ehiametalor (2002) who posited that education moves a nation on a fast lane of economic development and national transformation. In the light of these definitions, this study sees education as a tool for scientific advancement, economic breakthrough, national cohesion and competition in a globalizing world. Most developed nation considered education as the major key performance index for their transformation. Therefore, to prevent Nigeria from been disconnected from global reality, quality of our teachers and students must be in top form in order to translate knowledge intensive process to technology intensive process which will in turn affect capital intensive process thereby influencing economic and technological development.

Regrettably, over half a century after independence, Nigeria is still struggling with providing its citizens the basic skills required to be useful in a globalizing world. For Nigeria to be globally competitive, we must demand a global education (Flynn, 2010). Educating the youth to become global citizens will allow them to learn about the interdependence of the world's system (Fleet \& Winthrop, 2010).

Udoh and Akpa (2012) observed that Nigerian educational system is not addressing current global economic changes and as such must be planned to address such economic challenges in order to meet up with global standards through technology and agriculture. The National Policy on Education (2004) clearly outlined the needs and benefits for science, technical and vocational education. However, these areas have not been given adequate attention in most educational institutions in Anambra State. Coombs in Udoh and Akpa (2012) described educational planning as the planning of education system, it's curriculum, the balance of its different parts and its auxiliary services. Ezeh (2013) opined that educational planning is an effort aimed at determining future cause of action through the development of strategies for effective realization of set goals. Similarly, Amadi (1990) attested that educational planning involves organising learning experiences such that the end result brings a positive benefit to the society. The National Policy on Education (2004) maintained that the success of any system of education is hinged on proper planning, efficient administration and adequate financing. Consequently, education planners must channel Nigeria's education, to address the yarning desire for technological advancement in this global competitive world.

Advancement in technology changes the way industry works and it makes learning faster and more meaningful and knowledge learnt more massive. Technology refers to ethical practice of facilitating learning and managing appropriate technological process and resources. Technology is a system that combines technique and activities with implements and artifacts, within a social context of organization in which the techniques are developed, employed and administered. Technology alter patterns of human activity by making worlds that shape our culture and environment thereby creating a circle between humanity and technology each shaping and 
affecting the other. According to Mesthene in Thierer (2014) technology is the organization of knowledge for the achievement of practical purpose. Hughes (2012) defined technology as the effort to organize the world for problem solving so that goods and services can be invented, developed, produced and used. Nwankiti in Lawson (2002) asserted that technology is the systematic application of scientific Knowledge to practical issues. Technology is not a luxury rather it is a necessity. Technology provide a mean for survival and a tool for global competition. Technological development therefore includes the development of tools that permit the specialization necessary for promoting global competition.

Globalization according to Imam in Wokocha (2012) is the intensification of the world wide social relation which links distant localities in such a way that local happenings are shaped by events occurring many miles away. In his view Steger (2008) described globalization as a variety of accelerating economic, political, cultural, ideological and environmental process that are rapidly altering our experience of the world. Contemporarily, competition is a global concern and every nation is struggling to key into the race and Nigeria must do same. The World Economic Forum in Lapitskiy (2018) defined competitiveness as the ability of a country and its institutions to ensure stable economic growth. Similarly, this study sees global competitiveness as the ability of a nations' economic advancement to gradually and steadily progress in responding to global standards.

It cannot be overemphasized that in order to maintain the present global competition in the world today, proper implementation of our laudable educational plans must be a prominent focus. High quality implementation policies can have a significant impact on improving students' outcome needed for technological advancement. We need excellent diagnosis identifying strengths and opportunities, gentle relentless pressure and defensible approaches in order to improve the implementation of our educational programmes. The Cambridge English Dictionary (1995) defines implementation as the act of putting a plan into action. Implementation is a specified set of planned and intentional activities designed to integrate evidence-based practices into real-world settings (Mitchell, 2011). The researcher sees implementation as the execution of a plan, idea, design or policy which is necessary for the success of any planned intention. If this is the case, then there is need for proper planning and implementation to suit the current global demands and societal challenges. Olulube (2013) observed that for any educational system to truly develop, effective strategic planning and implementation are indispensable tools. The advancement in modern technological issues and global competition has made every nation to begin to re-address their education plans to fit global competition (World Bank, 2011). The former British Prime Minister Mr Tony Blair in his electioneering campaign in the year 2000 identified education as the first, second and third top priority programmes. This is because he identified education as a major instrument for national transformation. Similarly, the former deputy governor of Central Bank of Nigeria (CBN) and 2019 presidential candidate of the Young Progressive Party (YPP) Prof Kingsley Moghalu during a presidential debate, strongly observed that education is the major instrument of national transformation and economic advancement. He further stressed that we cannot fix our economy without first fixing our education and politics.

Today, the crises in Nigeria's education service delivery has persisted and even assumed wider proportion. Many countries have experienced educational backwardness for instance South Korea, China and a host of other countries suffered some of the ugly experiences Nigeria is going through, there education system was their major instrument of transformation and today, they rank among the foremost economic and technological powers of the world (Lawson, 2002). Drucker in Dike (2016) noted that the best way to predict the future is to create it. Nigeria is in dire need for proper educational planning and implementation strategies or could be left behind in the technological race and global competition.

\section{Statement of the Problem}

Nigerian education system has undoubtedly encountered a number of significant impediments in the last few decades and has continued to struggle with planning and implementation of educational policies. The impediments among which but not limited to includes: poor educational funding, inaccurate statistical data, political interferences, poor national economic and technological performances, manpower needs, mismatch between educational products and the demands of the economy, dwindling resources, haphazard application of scientific development, high unemployment rate and political insurgencies in most parts of the country. All these impediments have been traced to poor education quality output needed for national cohesion, technological advancement, economic boom and global competitiveness. The crux of this study therefore is to look at the perception of principals on the impact of effective educational planning and implementation on education system in secondary schools in Anambra state.

\section{Purpose of the study}

The study investigated the perceived impact of effective educational planning and implementation on education system in Anambra State. To achieve this purpose, the following objectives specifically sought to:

1. Examine the factors that will promote principals' administrative effectiveness in secondary schools in Anambra State. 
2. Find out the administrative constraints affecting effective educational planning and implementation in secondary schools in Anambra State.

3. Ascertain the impact of effective educational planning and implementation on students' quality output in Anambra State.

\section{Research Questions}

The following research questions were formulated to guide the study.

1. What are the factors that will promote principals' administrative effectiveness in secondary schools in Anambra State?

2. What are the perceived administrative constraints affecting effective educational planning and implementation in secondary schools in Anambra State?

3. What is the perceived impact of effective educational planning and implementation on students' quality output in secondary schools in Anambra State?

\section{Hypothesis}

There is no significant difference between the mean ratings of male and female principals on the factors that will promote administrative effectiveness in secondary schools in Anambra State.

\section{Methodology}

Descriptive survey design was used for the study. The population comprised all the principals in the public secondary schools in Anambra State numbering 257. There was no sampling due to the manageable size of the population of the study. Structured questionnaire with 24 items titled 'Perceived Impact of Effective Educational Planning and Implementation on Education System'(PIEEPIES) was used to collect data for the study. It was validated by three experts two in Educational Management and one in Measurement and Evaluation, all from the department of Educational Foundations, Chukwuemeka Odumegwu Ojukwu University, Igbariam Campus, Anambra State. Cronbach Alpha was used to test for reliability and an index of 0.89 was obtained. Two hundred and fifty- seven copies of the questionnaires administered to the respondents at their zonal meeting was properly completed and retrieved.

The research questions were analysed using the arithmetic mean, standard deviation and t-test was used to test the only null hypothesis at .05 level of significance. Items that attracted 2.50 and above on a four-point likert type scale were regarded as 'important' while items less than 2.50 were regarded as 'unimportant'.

\section{Results}

Research Question 1: What are the factors that will promote principals' administrative effectiveness in secondary schools in Anambra State?

Table 1: Mean responses of respondents on the factors that will promote principals' administrative effectiveness in secondary schools in Anambra State.

\begin{tabular}{llccl}
\hline S/N & Item Description & X & SD & Remarks \\
\hline 1. & Physical facilities & 3.40 & 0.64 & Important \\
2. & Finance & 3.81 & 0.38 & Very Important \\
3. & Manpower & 3.75 & 0.44 & Very Important \\
4. & Technological machineries & 3.67 & 0.47 & Very Important \\
5. & Unified curriculum content & 3.92 & 0.28 & Very Important \\
6. & Human and material resources & 3.50 & 0.65 & Very Important \\
7. & Learning environment & 3.33 & 0.63 & Important \\
\hline
\end{tabular}

The results on table 1 revealed that two items were considered important while five items were considered very important by the principals as items that will boost their administrative effectiveness as they all have a mean score above the criterion mean of 2.50 .

Research Question 2: What are the administrative constraints affecting effective educational planning and implementation in Anambra State? 
Table 2: Mean responses of respondents on administrative constraints affecting effective Educational planning and implementation in secondary schools in Anambra State.

\begin{tabular}{llccl}
\hline S/N & \multicolumn{1}{c}{ Item Description } & $\mathrm{X}$ & $\mathrm{SD}$ & Remarks \\
\hline 8. & Poor planning process & 2.72 & 0.84 & Important \\
9. & Inaccurate data & 3.40 & 0.64 & Very Important \\
10. & Unqualified manpower & 3.13 & 0.91 & Important \\
11. & Inaccurate budgeting & 3.06 & 0.97 & Important \\
12. & Insufficient fund for research work & 3.98 & 0.27 & Very Important \\
13. & Lack of motivation/incentives & 3.65 & 0.48 & Very Important \\
14. & Manual method of operation & 3.74 & 0.45 & Very Important \\
15. & Constraints relating to mobility and equipment & 3.50 & 0.65 & Very Important \\
\hline
\end{tabular}

The results on table 2 revealed that all the items outlined were major administrative constraints affecting effective educational planning and implementation in Anambra State, while the constraint of insufficient funding with mean score and standard deviation of 3.98 and 0.27 respectively was found as most devastating item.

Research Question 3: What is the perceived impact of effective educational planning and implementation on students' quality output in Anambra State?

Table 3: Mean responses of respondents on impact of effective educational planning and implementation on students' quality output in secondary schools in Anambra State.

\begin{tabular}{llccl}
\hline $\mathbf{S} / \mathbf{N}$ & Item Description & $\mathrm{X}$ & $\mathrm{SD}$ & Remarks \\
\hline 16. & Enhancing the quality of graduates & 3.17 & 0.90 & Important \\
17. & Enhances enthusiasm to learning & 3.25 & 0.60 & Important \\
18. & Reduces dropout rate & 3.04 & 0.98 & Important \\
19. & Enriches creativity and innovative ideas & 3.92 & 0.28 & Very Important \\
20. & Promote national unity and cohesion & 3.83 & 0.37 & Very Important \\
21. & Reduces tribal, cultural and religious sentiments & 3.01 & 0.99 & Important \\
22. & Promote inquiry, knowledge and rational mind & 2.92 & 0.87 & Important \\
23. & Promote effective communication & 3.81 & 0.38 & Very Important \\
24. & Promote understanding of the need for technology & 3.33 & 0.63 & Important \\
\hline
\end{tabular}

The result on table 3 revealed that all the items are strongly upheld by the respondents as the impact of effective planning and implementation on students' quality output with mean scores all above the criterion mean of 2.50 .

Table 4: t-test difference in the mean responses of male and female principals on their perception on factors that will promote administrative effectiveness in secondary schools in Anambra State.

\begin{tabular}{lcccccc}
\hline Source of variation & $\mathbf{N}$ & $\mathbf{X}$ & $\mathbf{S D}$ & t-cal & t-crit & Decision \\
\hline Female Principals & 160 & 3.60 & 0.50 & & & \\
& & & & 0.33 & 1.96 & NS \\
Male Principals & 97 & 3.62 & 0.49 & & &
\end{tabular}

The result on table 4 shows that the t-crit value of 1.96 is greater than the t-cal value of 0.33 at .05 level of significance. Therefore, the null hypothesis is accepted that there is no significant difference between the perception of male and female principals on the factors that will promote administrative effectiveness in secondary schools in Anambra State.

\section{Discussion of Findings}

The research questions were designed to find out the impact of effective educational planning and implementation on education system in secondary schools in Anambra State, Nigeria. Results in table 1 revealed that effective educational planning and implementation will be of immense benefit to the secondary school principals because it makes their administrative responsibilities more effective. When all the funds, machineries, resources and manpower needed to do the job are put in place, then the principals' job of ensuring a quality education output is guaranteed. This is in line with Olulube (2013) who asserted that for educational system to truly develop, effective planning and implementation which includes planning for adequate physical facilities, finance, human and material resources are indispensable tools. Similarly, the National Policy on Education (2004) also maintained that the success of any system of education is hinged on proper planning, efficient administration and adequate financing.

The result in table 2 revealed that the respondents considered poor planning process, inaccurate data, unqualified manpower, inaccurate budgeting, lack of motivation/incentives as well as manual method of operation as major constraints to effective educational planning and implementation. This is in line with the view of Iitau (2013) who maintained that the myriad of constraints to proper strategies for better educational management include budgetary constraints, manpower constraints, constraints relating to mobility and equipment, constraints relating to technical information, constraints in participation, policy constraints and others. 
The table further revealed that the constraint of insufficient funding was found as most devastating item. This is because the success of all other issues is centred on finance. Education sector has suffered in the area of budgetary allocation over the years. The global organization recommended the budgetary benchmark of 26 per cent to enable nations adequately cater for rising education demands but regrettably, Nigeria has not been able to make the benchmark (Otive, 2017). He further observed that the federal government budgetary allocation to education has been dwindling from 7.2\%, 10.55\%, 10.75\%, 7.92\%, 7.4\%, in 2013, 2014, 2015, 2016 and 2017 respectively and noted that with this poor educational funding, it will be very difficult for Nigeria to achieve its goals in meeting up with global standards. This reality tallies with the contention of Dike (2016) that Nigeria cannot benefit from the emerging global economy with the present poor state of budgetary allocation on education.

Considering the result in table 3, effective educational planning and implementation is bound to enhance the quality of graduates, enhance enthusiasm to learning, reduce dropout rate, enhance creativity and innovative ideas, promote national unity and religious sentiments as well as promote understanding of need for technology. In support of this finding, Verma (2018) pointed out that effective educational planning and implementation is absolutely necessary to ensure success of educational programmes, clarify goals, enhance creativity, save effort, time and money, eliminate trial and error as well as provide intelligent direction of activities

Finally, when all the parameters for effective planning and implementation are put in place, the quality output in terms of students' performance will be greatly enhanced, students will also want to put in their best to achieve success, and the overall goal of education as instrument of national growth and cohesion will be attainable. This view agrees with Udoh and Akpan (2014) who asserted that when education is made functional then it is capable of producing Nigerians who can transform the nation from a consuming one to a manufacturing one.

\section{Conclusion}

Based on the findings, it is imperative that Nigerian government should take concrete action by resolving the crisis in the education sector. Effective strategic planning and implementation seems to be the way out. Effective strategic planning and implementation is the heart of how to make changes in any organization. It enables any organization to achieve full and active executive performance, effective communication and high-quality graduates among others. If indeed education is considered a major instrument of national transformation, then Nigeria must work hard to translate her education to knowledge technology needed for economic advancement.

\section{Recommendations}

Based on the conclusion in this study, the following recommendations are made

1. Budgetary allocation on education sector should be reviewed to at least the 26 per cent minimum by UNESCO.

2. Education policies and plans should be reviewed to accommodate global challenges.

3. Well-equipped and functional technical workshops, laboratories, libraries and ICT system should as a matter of urgency be provided in all secondary schools in Anambra State.

4. Students who exhibit innovative ideas should be encouraged.

\section{References}

Aluwong, W.S. (2013). Entrepreneurial and functional education as means of achieving the national objectives of vision 2020 in Nigeria. International Journal of Education Research Development, 1(2), 1-7.

Amadi, W.S. (1990). Principles of curriculum development. Uyo: Legacy.

Cambridge English Dictionary (1995) Implementation defined. Retrieved from Https://www.dictionary.cambridge.org>implementation

Dike, V.E. (2016). The state of education and global competitiveness. https://www.gamji.com/article6000/NEWS6240.htm

Ehiametalor, E.T. (2002). Lesson from the past. The Nigerian Academic of Education, 1(4), 20-27.

Ezeh, C. (2013). Human resource management: Issues, development and utilization. Nimo: Rex Charles and Patrick Ltd.

Federal Government of Nigeria (2004). National policy on education. Lagos: NERDC

Fleet, J.V. \& Winthrop, R. (2010). Global competitiveness. Retrieved from Https://www.brookings.edu/blog/upfront $/ 2010$

Flynn, P. (2010). Global competition and education: Another sputnik? Retrieved from Https://www.tandfonlune.com $>$ doi $>a b s$

Hughes, T.P. (2012). Human-built world: how to think about technology and culture. University of Chicago Press. P.6

Ifeanacho, E. (2016). Poor leadership in the education sector: The epicentre of the decline in the growth of 
Nigeria. Onitsha: University Publishing Company.

Iitau, N. (2013). Constraints to effective planning and implementation of workers education in Teacher union: A case of Zambia National Union of Teachers. Retrieved from https://wwwdspace.unza.zm>xmlui $>$ handle

Lapitskiy, I. (2018). Global competitiveness. Retrieved from Https://wwwnigeria.opendataforafrica.org $>$ clwiine Lawson, O.S. (2002). Technological development in maintaining national integration and cohesion. Journal of Knowledge Review 5(3), 103-109.

Mitchell, P.F. (2011). Evidence-based practice in real-world services for young people with complex needs. Children and Youth Service Review, 33(2), 207-216.

Olulube, A.O. (2013). The problems and approaches to education in Nigeria: A theoretical observation. PortHarcourt: MCSER Publishers.

Otive, I. (2017). Nigerian budget. What are the issues? Retrieved from Https://www.gamji.com/article1000/NEWS10468.htm

Steger, M.B. (2008). Globalization. Retrieved from https://www.thriftbooks.com/

Thierer, A. (2014). Defining “Technology”. Retrieved from https://techliberation.com>2014/

Udoh, A.O. \& Akpan, O.E. (2014). Functional education: Rising vocational skills in a global economy. International Journal of Research in Humanities, Art and literature, 2(6), 23-37.

Udoh, S.U. \& Akpa, G.O. (2012). Educational administration in Nigeria: theory and practice. Jos: M.P. Ginac Concept Ltd.

Verma, D. (2018). Reason why educational planning is important. Retrieved from https://www.shareyouressays.com $>$ knowledge

Wokocha, A.M. (2012). Education, leadership and human resource development for today's World. IJERD. Faculty of Education, UNIZIK, 4(1).

World Bank, (2011). The promotion of social cohesion through education. Retrieved from Https://www.openknowledge.worldbank.org/handle/10986/18013 